\title{
The Quest for a Canadian Naval Strategy 1991-2014: Why it Matters
}

\section{Rob Huebert}

La fin de la guerre froide avec l'effondrement de l'Union soviétique était un événement heureux pour la sécurité mondiale, mais elle a créé un nouvel ensemble de défis pour la marine canadienne. Les planificateurs de la marine canadienne ont dû développer une nouvelle stratégie navale sans le socle jusqu'alors fourni par l'OTAN. Ce document examine les trois questions principales qui ont dominé l'effort de développer la nouvelle stratégie: premièrement, quelles sont les missions et les actions fondamentales de la marine canadienne après la fin de la guerre froide? Deuxièmement, quelles sont les capacités ou les instruments nécessaires pour répondre à ces besoins? Et finalement, comment engager les élites politiques canadiennes et la population à soutenir cette stratégie?

Celebrating the centennial of the existence of the Royal Canadian Navy reminds Canadians not only that the country has a navy - but that it has had a need for the navy throughout its last hundred years. From its creation just before the onset of the First World War; to the pivotal role it played in the Second World War; to its conduct during the Cold War; to its current status as a modern blue water navy - successive Canadian governments have found critical roles for the navy to play. Its history proves its utility as an instrument of force in the defence of Canadian national security. Canadian leaders often come to power with an ignorance of the value that the navy has to Canada, but very quickly learn of its importance.

Within its central role in the maintenance of Canadian national security throughout the last hundred years, the question may be asked - what has this success been based on? Or more to the point - what is the Canadian 'naval strategy'? Why does the Canadian navy need a strategy? What are some of the challenges that are faced in creating such a strategy? What does it mean for the ultimate development and deployment of Canadian sea power in the modern era?

Canadian naval historians such as Marc Milner and others have demonstrated that there have been elements of a Canadian naval strategy throughout its history. ${ }^{1}$

1 Marc Milner, Canada's Navy: The First Century $2^{\text {nd }}$ edition (Toronto: University of Toronto Press 2010), and Ann Griffiths, Peter Haydon and Richard Gimblett (eds.), Canadian Gunboat Diplomacy: The Canadian Navy and Foreign Policy (Halifax: Centre for Foreign

The Northern Mariner/Le marin du nord XXIV, Nos. 3 \& 4 (Jul. \& Oct. 2014), 324-335 Canadian Military History 23, Nos. 3 \& 4 (Summer \& Autumn 2014), 324-335 
Choices were made as to the type of instruments that were procured and utilized. The Canadian navy has been on the winning side of every major war (hot and cold) that it has fought. Many of these decisions can be characterized as a strategy born of necessity and not the result of a formal process. Nevertheless, there were certain things that the navy was not able to do and there are other tasks that it could realistically attempt to achieve. Choices were made that meant there was an implicit Canadian naval strategy. As Milner and the others have shown, it may have been as simple as supporting the United Kingdom as a distinctly Canadian navy, or it may have been a more complicated strategy based on supporting alliance needs while carving out a uniquely Canadian role within an antisubmarine specialization. Nevertheless, it is possible to trace the efforts of the leadership of the navy specifically (and the Canadian forces in general) to allow the more effective utilization of limited resources at its disposal, and which ultimately can be described as a Canadian naval strategy.

\section{Challenges in the Creation of Canadian Naval Strategy}

In spite of this history there are major challenges to the modern effort to enunciate a Canadian naval strategy. The reasons are numerous. Some of the most important are as follows. First, it is assumed that the Canadian navy will never operate by itself in a modern war environment. It may operate by itself for the protection of the maritime zones immediately adjacent to the Canadian coast, and it may act alone in the protection and enforcement of Canadian laws and regulations on a constabulary basis. But when it comes to fulfilling its core mandate to fight, it is expected that the navy will be fighting alongside allies and friends. Since its main allies have traditionally been some of the most powerful maritime states in the international system, it is also assumed that the Canadian navy will play a supporting role to the objectives and strategies of its bigger partners. Therefore, the reasoning goes, why bother developing an independent Canadian strategy if in fact the major strategy is to cooperate with its allies?

A second argument against the creation of a specific Canadian naval strategy relates to the developing efforts of successive Canadian governments in the post-Cold War era to control policy development. ${ }^{2}$ In order to speak with one voice, governments have been reluctant to allow the individual service branches to develop their own strategy. The preference is to have one strategy for the Canadian forces from which all other strategies then flow. This thinking suggests that in the current political environment, the Canada First Defence Strategy ${ }^{3}$ provides the guidance necessary for the navy to understand what its core needs and requirements are. The current government does not want an independent strategy from each of the forces because the strategies may

Policy Studies, 2001).

2 Donald Savoie, Governing from the Centre: The Concentration of Power in Canadian Politics (Toronto: University of Toronto Press, 1999), and his Whatever happened to the music teacher? How governments decides and why (Montreal and Kingston: McGill-Queen's University Press, 2013).

3 Department of National Defence, Canada First Defence Strategy (Ottawa: 2008), at: http://www.forces.gc.ca/en/about/canada-first-defence-strategy.page, accessed 20 September 2014. 
deviate from their overall defence policy. How then is the navy to develop a 'stand alone' strategy in the face of such a constraint?

The third argument against the development of a modern Canadian naval strategy is that it would quickly become dated. This concern is based on the assumption that the post-Cold War international environment is in such a rapid state of transformation that events will render any published strategy obsolete in a very short time. It therefore would be more of a hindrance than a guide. This suggests that there is a greater utility to playing it 'by ear' as events develop rather than having a specific policy.

Finally, the argument also is made that if the Canadian forces - including the navy - 'do', they do not 'think'. This suggests that any effort to take away from core activities diverts scarce resources from more necessary tasks. It further suggests that the Canadian navy and the Canadian forces in general do not have the capacity to be able to act and to think at the same time.

Each of these arguments is problematic and flawed. The suggestion that Canada should not bother with its own strategy because it can always depend on larger partners to spend the effort to develop their strategy misses entirely the point of having a strategy. The ultimate objective of a Canadian naval strategy is to ensure that Canadian national interests are served by the Canadian navy. It may be that these interests are indeed served through close cooperation with its allies, and that there is a need to be sensitive to the naval strategies of countries such as the United States and the United Kingdom. But ultimately any cooperation with these or other allies is to provide for Canadian security and the promotion of Canadian interests.

At the same time there can never be a suggestion that a Canadian naval strategy is somehow separate from the core policies of the Canadian government. Canadian governments must retain ownership of Canadian defence policy. But to suggest that such a need of ultimate civilian control negates the ability of the navy to develop a strategy specific to its operating environment is short-sighted. It may make the task more difficult but it does not make it impossible. Given the importance of the subject, a means of cooperation must be found. The development of a national shipbuilding strategy ${ }^{4}-\mathrm{a}$ task that no other Canadian government has been able to develop in the last half-century also demonstrates that, even under the present Conservative government of Prime Minister Stephen Harper, with its reputation for tight control, the navy still can participate in an informed and intelligent strategy formulation process.

The rapid and continual transformation of the international security environment does not validate the argument that it is impossible to develop a strategy that can be responsive quickly enough to changes. Rather, the existence of such an environment amplifies the need for the development of a strategy to offer guidance in confounding conditions. In any rapidly transforming environment, decision-makers within both the navy and the government need to think prior to the onset of an emergency how best to

$4 \quad$ Public Works and Government Service National Shipbuilding Procurement Strategy (3 June 2010), at: http://www.tpsgc-pwgsc.gc.ca/app-acq/sam-mps/snacn-nsps-eng.html, accessed 20 September 2014. 
utilize the navy. Simply assuming that it will be possible to create ' $a d$ lib' responses to new events and crises is a recipe for disaster. The strategy that takes into account that it is necessary to be both sound and flexible will provide decision-makers the proper framework by which they can achieve the highest utility through the deployment of Canadian sea power.

Finally the contention that the Canadian forces and the Canadian navy 'do' but do not 'think' is wrong on so many counts as to almost be offensive. The history of strategies that have been developed within the navy and other branches of the forces points to the ability of Canadian sailors, soldiers and air personnel to both 'do and think'.

\section{Why is there a Need for a Canadian Naval Strategy?}

The arguments against the creation of a Canadian naval strategy are misplaced and wrong. So what are the arguments in favour of having a Canadian naval strategy in the current time? First there is the need to respond to the changing nature of sea power in the modern era. New technologies are now transforming how sea power can protect the national interest of any maritime state. Just as the introduction of the technologies that allowed the United Kingdom a century ago to design and build the all-big gun battleship HMS Dreadnought transformed the concept of sea power at that point, new technologies involving communications, detection and weapons now require equivalent transformations of theories of sea power. ${ }^{5}$ This is not just for Canada but for all maritime powers. Understanding what these new technologies mean in regards to utilizing sea power for both defensive and offensive objectives requires careful considerations of what sea power represents in the current international system. The thinking required behind such issues cannot be done on a piecemeal and reactive fashion. It must be undertaken in the context of a carefully considered and developed strategic process.

This leads to the second factor requiring Canada to be able to think clearly about the best use of its navy. The international system is changing in ways that are surprising to most observers. This transformation means that Canada faces new challenges and has new opportunities for protecting and promoting its interests through the world's oceans. Prior to September 2001, few analysts and decision-makers, let alone the population at large, could have anticipated that Canada would deploy the majority of its naval capability in support of a combat mission in Afghanistan. Given the fact that Afghanistan is a landlocked country, it seems improbable that it would become a major focus of Canadian sea power. And yet Operation Apollo was one of the most intensive uses of Canadian sea power in decades, and achieved numerous Canadian national objectives. ${ }^{6}$ Currently the dramatic decline in the western relationship with Russia has created new

$5 \quad$ For a general discussion, see Elinor Sloan, The Revolution in Military Affairs (Montreal and Kingston: McGill-Queens University Press, 2002). For a more specific Canadian examination, see Allan English, Richard Gimblett and Howard Coombs, Networked Operations and Transformation: Context and Canadian Contributions (Montreal and Kingston: McGill-Queen's University Press, 2007).

6 Richard Gimblett, Operation Apollo: The Golden Age of the Canadian Navy in the War Against Terrorism (Ottawa: Magic Light Publishing, 2004). 
challenges for the Canadian navy that most had assumed would not re-occur. In order to best meet these challenges, a strategy that assists decision-makers on how best to achieve the optimum outcome through the use of Canadian sea power is necessary. Simply acting on an ad hoc and reactive basis may be successful at times, but this becomes more of an element of luck than what is achieved through proper planning in the long term.

A third requirement for a comprehensive but flexible naval strategy is to assist in the procurement process of acquiring new assets. The Harper government has taken steps to rationalize its shipbuilding strategy. It seems determined to avoid the mistakes of past governments, which saw large numbers of Canadian naval units built in a short period of time. That past practice has created numerous dysfunctions for the Canadian navy. It meant that it was necessary to ramp up and then close down existing Canadian shipbuilding capacities, adding to construction costs. It also has meant that when a class of vessels becomes obsolete, there is a mass obsolescence of a large number of vessels. The Canadian government is now planning to build a smaller number of ships at any one time, but on a continual basis, much as the Americans have done with their aircraft carriers and submarines.

This should rationalize the process. But the question then follows as to what ships should be built? This decision will ultimately be the result of careful consideration between the political elites and the leaders of the navy. But by having a naval strategy that has been developed by the Canadian service itself, naval leaders are in a better position to determine what type of ships and other assets should be built for the Canadian navy. It is no longer sufficient to be able simply to replace the preceding class of vessels with newer and better ones. It is always necessary to determine what the optimum composition of the navy should be for the current time and the future, rather than simply replacing old ships. A naval strategy will not be the only guide in reaching the best decisions, but it can provide an important guideline when it is developed carefully and intelligently.

A fourth reason for the development and maintenance of a Canadian naval strategy pertains to the relationship between the navy and the general Canadian population. Canadians do not always appreciate and understand why Canada has and needs its navy. In part, this is driven by the reality that the bulk of the Canadian population lives in the interior away from the coasts. Even in the case of British Columbia, the main naval base serving the Pacific Ocean is found in Victoria and not the larger metropolitan area of Vancouver. Canadians seldom see the navy in action and have even less of an opportunity to understand its importance. A Canadian naval strategy provides both the navy and Canadian governments with a document that will help explain why we need a navy. It is not a panacea for this problem, but if it is written in an engaging fashion a strategy can help explain why a navy is needed. Used correctly such strategies also will explain to the public why it is necessary to engage upon certain activities. They should not be the major purpose of having such a strategy, but it can provide an important instrument to educate the general population on what it is that the navy does and perhaps even more important why it does it. 


\section{What are the Key Elements of a Modern Canadian Naval Strategy?}

Of the three branches of the Canadian forces, the navy has had the most extensive experience in drawing up an overarching strategy. This is not to suggest that the army and the air force do not think in strategic terms, but to point out that historically it is the Canadian navy that has engaged upon this activity the most. This can be traced to three major reasons. First, the navy has a history that connects to the development of the strategic overview more readily than the other two forces. ${ }^{7}$ Modern western navies all point to the work of naval thinkers such as Mahan and Corbett to develop core concepts of sea power upon which strategies at the broadest levels can then be developed. ${ }^{8}$ There is a tradition in western navies to think in such common terms that is further reaching that for land and air forces. In part this flows from the second reason why western navies - including Canada's - are pre-disposed to thinking in strategic terms, and comes back to the issue of the relationship between procurement and strategy. Naval assets are expensive and large. To justify the large effort and heavy costs to build warships, it has been necessary for western naval leaders to enunciate why it is that they need a particular type of navy. As discussed previously, decisions are made more efficiently if governments can explain what units are needed and why they are needed. Thirdly, there is a well-established tradition of the relationship between sailor and scholar. This flows particularly from the American effort to ensure that its navy is developed in a rational and intelligent manner. ${ }^{9}$ As a result, one can see the influence that a sailor-scholar such as Mahan has had on their traditions. All of these factors have influenced the Canadian naval community.

The results of this historical foundation have informed Canadian understanding of sea power, which then informs Canadian naval strategy. While it goes beyond the scope of this paper to provide a detailed analysis of Canadian concepts of sea power, the following main points can be made.

It is the writings of the modern British writers Ken Booth and Eric Grove that have had the strongest influence on Canadian naval officials in framing a naval strategy. ${ }^{10}$ This flows from the need to develop a framework that can be utilized for a medium-sized navy. The writings of Mahan and Corbett generally are considered to focus on the navies of the most powerful states. Therefore, there has been a tendency to attempt to apply the works of sea power analysts who have incorporated the needs of medium powers to provide the basis of Canadian understandings of sea power. The most explicit

7 Colin Gray The Leverage of Seapower: The Strategic Advantage of Navies in War (New York: The Free Press, 1992).

8 Alfred Mahan The Influence of Sea Power upon History, 1660-1783 (Boston: Little Brown and Co., 1892); and Julian Corbett, Some Principles of Maritime Strategy (Annapolis: Naval Institute Press, 1988).

9 For a good discussion see Geoffrey Till, Seapower: A Guide for the $21^{\text {st }}$ Century $3^{\text {rd }}$ edition (London and New York: Routledge: 2013), 45-86.

10 Ken Booth, Navies and Foreign Policy (London: Croom Helm 1977) and his Law Force and Diplomacy at Sea (London: George Allen and Unwin, 1985). Eric Grove, The Future of Sea Power (London: Routledge, 1990). 
documentation of this orientation has been provided through Leadmark. ${ }^{11}$ One of the most comprehensive efforts to develop a Canadian naval strategy, it unequivocally drew its foundation primarily from the works of Booth and Grove. Sea power for medium navies, according to these analysts, is utilized for three main objectives: war fighting; foreign policy; and constabulary functions. Leadmark employed these three categories to explain the purpose of the Canadian navy in the modern era.

Somewhat paradoxically, the core elements of the post-Cold War Canadian naval strategy began before the conflict ended. In an effort to deal with the transforming elements of the later Cold War, the Conservative government of Prime Minister Brian Mulroney issued a Defence White Paper in 1987 entitled Challenge and Commitment. ${ }^{12}$ This document was an effort to respond to what the government saw as a changing Cold War. The interaction of the new leadership of the Soviets following the death of Leonid Brezhnev in 1982 and American President Ronald Reagan had created a new dynamic. As such, the 1987 White Paper focused on developing a Canadian military strategy that would provide protection in the context of an evolving USSR/US security relationship and provide guidance for dealing with a changing international security environment. It is best remembered from a maritime perspective for the proposal to acquire nuclearpowered submarines for the Canadian navy. But it was more important in its effort to develop an overall strategy that placed a premium on flexible, professional combat ready forces that served Canadian security and national interests. The document retained a commitment to Canada's allies, but it also moved towards a Canadian defence policy that attempted explicitly to place Canadian interests as its top priority.

The overall strategy that flowed from this document was criticized for being too focused on the remnants of the Cold War. ${ }^{13}$ More important, the programs that were identified to support this strategic viewpoint soon fell victim to the government's other efforts to address the rising Canadian deficit. With the reduction of the military threat posed by the former USSR as the Cold War unexpectedly ended and the rising recognition of the danger posed to Canadian economic security by a rapidly accelerating deficit, this particular strategy was soon abandoned.

However, the efforts by the subsequent Liberal government of Prime Minister Jean Chretien to develop an overall military strategy allowed the opportunity for naval officials to develop their own naval strategy under the umbrella of the 1994 Defence White Paper. ${ }^{14}$

11 Department of National Defence, Leadmark: The Navy's Strategy for 2020 (Ottawa: Directorate of Maritime Strategy, June 18, 2001), 27-50.

12 Department of National Defence, Challenge and Commitment: A Defence Policy for Canada (Ottawa: Department of National Defence, 1987).

13 See for example Fen Hampson "Call to Arms: Canadian National Security Policy," in Maureen Molot and Brian Tomlin (eds.), Canada Among Nations: A World of Conflict 1987 (Toronto: James Lorimer, 1988), 72.

14 Department of National Defence, 1994 White Paper (Ottawa: Canada Communication Group, 1994). 
The first effort was the Naval Vision $1994 .{ }^{15}$ This provided for a discussion of the need for a Canadian navy in a rapidly changing international environment and consideration of some specific issues . The navy no longer faced a direct Soviet threat, but it was increasingly being called upon to act in ways that had been unanticipated, such as the deployment under United Nations auspices in response to the Iraqi invasion of Kuwait. ${ }^{16}$

The tempo of operations then continued to increase, necessitating further thinking on the strategies that needed to be used. This resulted in the document Adjusting Course: A Naval Strategy for Canada. It states:

(t)he end of the Cold War removed the strategic certainties that had long bound our horizon. We're faced with the challenge of crafting a truly national stance on the world stage, one unencumbered by colonial baggage and less dependent on alliance considerations... [Adjusting Course] embodies [the maritime staff's] professional consensus, and provides a common frame of reference for consideration of maritime issues, hopefully as a catalyst for thought. ${ }^{17}$

This identified the need and importance of a distinctly Canadian naval strategy to best serve Canadian national interests.

In 2001 Leadmark was released, representing the most extensive effort to develop a modern Canadian naval strategy. The document was extensively researched and presented a very determined effort to develop a strategy on an intellectual and rational basis. As then-Chief of Maritime Staff Vice-Admiral Greg Maddison stated in its introduction, "Leadmark examines the principles of naval strategy essential for a medium power such as Canada." 18 The document itself states that it "stands on its intellectual underpinning. It provides a point of reference for consideration in deciding the structure of the Canadian navy and putting the navy to use in the defence of Canada and in opening the road to our future." ${ }^{\prime 19}$ Its main three themes were that:

1) there was a requirement for a flexible combat capable blue water navy;

2) there was a need to retain an ability to work with the best and most advanced navies of Canada's allies and friends;

3) and that Canadian sea power was an integral element of protecting and promoting Canadian national interests and Canadian national security.

The document made explicit the linkage between having a well-designed strategy and the best use of the navy. It determined that Canadian national interests, regardless of

15 Department of National Defence, The Naval Vision: Charting the Course for Canada's Maritime Forces into the Next Century (Halifax: Canada Communication Group, 1994).

16 Duncan Miller and Sharon Hobson, The Persian Excursion: The Canadian Navy in the Gulf War (Clementsport, NS: The Canadian Peacekeeping Press, 1995).

17 Department of National Defence, Adjusting Course: A Naval Strategy for Canada (Ottawa: Canada Communication Group, 1997), iii.

18 Leadmark, i.

19 Ibid., 6. 
the Canadian tendency to look only to land, were completely tied to the oceans. The oceans not only provide a critical component to the economic security of Canada, they also provide an important defensive buffer that needed to be maintained even in the post-Cold War era.

The impacts of Leadmark were substantial. It provided the justification for retaining a naval capacity that could operate almost anywhere on the globe (with the ironic exception of the arctic region). This meant that the high degree of readiness retained by the Canadian navy throughout the 1990s continued into the 2000s. When various international crises occurred, it was the navy that often was the first force to be deployed. The government response to the 11 September 2001 terror attacks and the ensuing Afghanistan crisis best exemplifies and illustrates the Canadian naval ability to respond quickly and massively. Operation Apollo ultimately involved almost every one of the larger ships of the Canadian navy.

Leadmark also identified the need to be able to operate with the best and biggest navies. This then provided a policy background for the practice of deploying Canadian vessels with American carrier battle groups. Following a successful deployment of the then-new Canadian Patrol Frigate HMCS Regina 'integrated' into a US Navy surface task group in 1997, another frigate, HMCS Ottawa, similarly deployed with an American aircraft carrier battle group in 1998, establishing that a Canadian warship was able to perform at an operational level equal to that of its American counterparts. This capability was further showcased in a wide array of subsequent deployments with the ability of Canadian naval flagships to take command of allied formations in various deployments to the waters surrounding the Middle East.

The development of all of these documents has also had the benefit of developing an ethos of strategic thinking in the navy. Not only does the culture that is created through such sustained analytical efforts indoctrinate the professional development of the navy, it has also had an impact on the army and air force. Neither of those forces have had an established tradition of putting forward their own strategic doctrine in a format similar to that of the navy. But the subsequent development of 'vision' documents for the air force and the army demonstrate that such intellectual exercises as the development of a written strategy are now seen as useful by all branches of the forces. ${ }^{20}$

Regardless of the multiple benefits that are provided through developing and maintaining a Canadian naval strategy, there are still numerous challenges to this process. These flow from the more general obstacles identified in the beginning of this paper.

First, and perhaps insurmountable, is the fact that Canada and its political elites retain a landlocked mentality. There are very few decision-makers who fully understand that Canada is a maritime nation and must depend on its navy for its maritime security. This means that there is a longstanding tendency to ignore the navy and hence a failure to address its core requirements.

The second challenge in the post-Cold War era has been associated with the lack of 
a clear 'enemy'. Maintaining and preparing a naval strategy when there is no clear enemy begs the question 'why bother?' Unfortunately historical precedent suggests that this is precisely the time when a naval strategy is needed. In the 1920s, the western democracies were uncertain as to who they would face as naval enemies. When new threats did appear, the lack of preparation hindered western response to the rising naval threats posed by Japan, Germany and Italy. Without a clear understanding of who or what is the threat, it is difficult to know how best to prepare.

Third, Canadian naval requirements require cooperation with the Canadian Coast Guard. But given the different cultures and mandates of the two institutions, it has been difficult to cooperate in developing a shared 'maritime' strategy. There is reluctance in the coast guard to see itself beyond being a service provider. As such, it has not developed its own institutional strategy. Likewise the navy has found it easier to focus on a naval strategy rather than a maritime strategy that would include the needs and objectives also of the coast guard.

Fourth, the escalating costs of ships confound any effort to develop a naval strategy that goes beyond traditional needs of the navy. Naval vessels are now becoming so expensive to build that it is often tempting simply to replace existing classes with new and updated variants. This has the advantage of allowing the navy to continue to do what it has done in the past. It also prevents the acquisition of a new and potentially expensive class of vessels that may not meet Canadian needs. It begs the question, what is the best way of preparing for the future? Continue to advance on an evolutionary process based on updating past experiences? Or possibly introduce revolutionary change through a process based on strategy development? It is understandable why naval decision-makers would be reluctant to move too far away from processes that have been successful in the past.

Fifth, the confounding impact of new technologies has always challenged naval thinkers to respond to new developments. The sequential development through the past century of Dreadnaught battleships, then aircraft carrier task groups and nuclear-powered submarines all represented efforts to develop new technologies that re-cast the very nature of naval warfare. What is changing now is the speed by which new technologies are advancing. Cyber warfare, new missile technologies, and nanotechnology are but the best known examples of new requirements that the navy must take into consideration when developing its naval strategy. The task is complicated further by the need to build new ships that can incorporate the new technologies in both defensive and offensive means. This is indeed a very difficult task.

Sixth, it indeed is easier to 'do' rather than to 'think'. There will be senior naval leaders who will prefer simply to be 'given the tools' to 'do the job' and get on with the task, rather than continually thinking about what the tools should be, or what is the 'job'. And once a naval vessel is built, the Canadian tradition is to maximize its life cycle, which means that there will over time be natural constraints as to what the navy can and cannot do. Any strategy therefore that ignores this reality faces irrelevance.

Seventh, there is an increasing trend in Canadian policy making that increasingly is making it difficult for the navy to develop a strategy that goes beyond Leadmark. The Harper government has more and more centralized the policy formulation process. While it 
goes beyond the limits of this paper to provide a proper consideration of this general public policy question, there are indications that the present government does not approve of any policy process that substantially deviates from its policy. By itself, this is not different from preceding Canadian governments. What seems to be different is the degree to which the current government is attempting to control all processes.

The navy has attempted to update Leadmark with a new strategy to be known as Horizon 2050. There was an extensive process by which naval experts were consulted with regards to the formulation of an updated and/or new strategy. This would have represented logical and rational continuation of the process pioneered in the creation of Leadmark. However, while this process was completed several years ago, there has been no official release of the updated strategy. There has been no official explanation, but several observers have suggested that it is probably related to the reluctance of the current government to approve significant strategies that are developed outside of existing policy framework. If this is true, it does create a significant challenge to the process. The democratically elected civilian government must always retain control over the direction of the armed forces of Canada. But how then does the navy in its professional capacity develop a meaningful strategy? This is not an easy question to answer. It raises fundamental questions about civil-military relations. Perhaps it is necessary to re-think some of the mechanics of the process of drawing up naval strategy by actively including members of the central political agencies. Of course this then raises the issue of political interference in the professional requirements of the navy. Ultimately the resolution of this particular challenge goes beyond the scope of this paper, but it obviously needs further thought. Still, the fact that the government and the navy were able to create a National Shipbuilding Strategy does underscore that it is possible.

\section{Conclusion}

This consideration of the need for a Canadian naval strategy and the process to develop it on an ongoing basis leaves more questions than answers. But there are six conclusions that can be reached.

First, one of the core challenges and needs of a Canadian naval strategy is the focus on the next fleet. The navy is a dynamic instrument that is continually responding to new environments, technologies and international relations. One of the key focal points of any strategy is to continually address the question of what are the best instruments to ensure the maintenance of Canadian maritime and national security.

Second, the navy must now prepare for a substantially expanded role in the Pacific and Arctic regions. The emerging global security environment will require the navy to increasingly have a presence in all three of its oceans. The 'luxury' of focusing primarily on the Atlantic Ocean increasingly is becoming a thing of the past. The Atlantic Ocean will remain important but the Pacific and Arctic Oceans will increase in importance to Canadian maritime security.

Third, there is the continual need to engage not only the Canadian public but also even more importantly the Canadian government. The structure of Canadian policy making is evolving. There are processes that are recasting how government operates in 
Canada. The development of a Canadian naval strategy must be created in a manner that recognizes and incorporates these new changes if it is to be effective.

Fourth, the development of a Canadian naval strategy prepares the navy's 'best and brightest' to think strategically. It is necessary to ensure that the officers who are assigned the task of developing the strategy be selected from the best critical thinkers the navy has. The process also needs to include a continual re-evaluation. The strategy itself should represent a written document that provides guidance for the navy, but mechanisms need to be in place to ensure that it is able to respond to a continually evolving security environment. This can only be achieved by ensuring that this remains one of the highest priorities of the navy and retains the continuing interest of its very best thinkers and leaders.

Fifth, the ultimate objective of this strategy always needs to be focused on Canadian national interests and security. However, given Canada's particular history, geography, size and culture, it will always need to be working with its allies and friends. This means that a strategy should be coordinated with the closest of them, bearing in mind that it must never be subservient to those same allies.

Sixth, it needs to be premised on a modern understanding of Canadian sea power. It needs to be a realistic document that avoids being 'politically correct' and recognizes the ultimate task of the navy is to be able to threaten or to employ the use of deadly force. The strategy needs to recognize that the navy needs to be prepared to act against those who would be willing to use deadly force against Canadians. This is an issue area that few Canadians wish to acknowledge, but one that must be addressed head-on if the strategy is to be useful and realistic.

Canada needs a modernized naval strategy to ensure that it is able to respond to the challenges and threats of the modern international security environment. Since these threats are continually evolving it is necessary that Canadian naval strategy must be a process. Leadmark got it right. It was a process that was intellectually rigorous, realistic, and engaged the full attention of its leaders and best thinkers. The Leadmark strategy was not a public relations exercise. It did not 'sugar coat' the challenges that Canada faces in protecting its maritime spaces and interests, and was willing to recognize Canadian shortcomings. This is precisely the type of document that is necessary. Unfortunately, the process to ensure that the strategy developed within Leadmark remains relevant does not seem to be working. It is nearly a decade and a half since that document was produced, and while it has served Canada well, it is necessary for it to be updated and revised.

The Royal Canadian Navy has defended Canadian national interests for over 100 years. It has done this with the highest professional standards that have allowed a relatively small nation to have one of the most modern and globally capable navies in the world. This is a testament to the sailors who put their lives at risk every day for the sake of the national interest. A national Canadian naval strategy is but one tool that allows this job to be done, but it remains a critically important one. It behoves Canadians to ensure that it is done correctly. 